$\mathrm{A}$ 型暗室灯 $=11.5[r L X] \quad \mathrm{B}$ 型暗室灯 $=2.7[r L X]$

$\mathrm{C}$ 型暗室灯 $=1.2[r L X]$

で照度 $11.5[r L X]$ の暗室灯は大体50湹の距離において新 聞の活字が全部誈める明るさです。

フィルム法について

暗室灯の直下において 10 糎 25 粝 50 粧 100 糎 150 糧の距離 で 2 分から 2 分でとに 5 段階の露光度行なった。濃度計 はイーストマンコダックを使用し露光10分間の場合ベー ス浱度+フォグの状態になる距離は次の通りである。

\begin{tabular}{c|r|r|r} 
フイルム名 & $\mathrm{A}$ 型暗室灯 & $\mathrm{B}$ 型暗室灯 & $\mathrm{C}$ 型愔室灯 \\
\hline フシフイルム & $50 \mathrm{~cm}$ & $25 \mathrm{~cm}$ & $10 \mathrm{~cm}$ \\
サクラフイルム & $150 \mathrm{~cm}$ & $50 \mathrm{~cm}$ & $25 \mathrm{~cm}$ \\
$\mathrm{E} ・ \mathrm{~K} フ ィ$ フル & $100 \mathrm{~cm}$ & $50 \mathrm{~cm}$ & $25 \mathrm{~cm}$ \\
\hline
\end{tabular}

現像剤の相違によるカブリ

各フィルムごとに 3 社の現像剂走使用し各標準現像時 間で処理を行なった結果フジフィムトレンドール EK フィルムトコニドールXがカブリは一番少なかった。た だし辐光時間は10分間です。

[結諭】

暗室灯の安全度は各メーカーにより相当の相違がある が暗室灯の最大照度は大体 $11.5[r L X]$ 程度と考えられる。

\section{9. ${ }^{137} \mathrm{Cs}$ 短距離照射における線量分布 (とくに表層部 の線量分布について)}

大阪赤十字病院放射線科 福岡勝
日立製作所 亀戸工場 馬場 勝彦
京都大学医学部放射線医学教室

〔目的】短距離照射の有用性は, 特定部位の照射にお いて,古くから Ra老用いて認められており, 近封は ${ }^{60} \mathrm{Co}$, ${ }^{137} \mathrm{Cs}$ が代って用いられるるうになった。しかし，照射 距離 $25 \mathrm{~cm}$ 以下では, 照射筒あるいは絞りの先端と皮膚 面が接近し, このため, 高エナージ $\gamma$ 線の特色である低 表面線量（skin sparing effect）が失われるおうれがあ

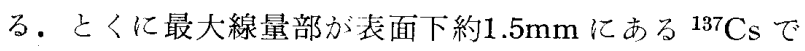
は，乙の特色が失われやすいと考えられる。この点に注 目して， ${ }^{137} \mathrm{Cs}$ の線量分布上くに表層部の線量分布を調 べ, 表層部線量の増加し学いような方法を見出さんとし た。

〔方法】自製薄壁扁平電離槽（壁厚 $3.5 \mathrm{mg} / \mathrm{cm}^{2}$, 電離 容積約 $0.25 \mathrm{~cm}^{3}$ ) 荞使用して, 照射筒, フィルターの条 件を種々変更して，線量分布を調べた。

〔結果】袁層部線量分布は, 照射野, 照射筒先端々表 面間距離, 照射筒の型,フィルターなどで大きな影響を
うける. 全体の線量分布は良好に保ちつつ, 表凰部の線 量老少くするためには, 照射筒の構造, フィルタ一, 照 射方法などに注意する必要のあることが分った。

100. リニアスキャナーの試作研究

東芝玉川工場

西堀清美・小野体雄・栗原重䅛

〔目的〕放射性同位元素党経口あるい注射投与しき の全身的分布および時間的変化の過程を测定記録し, 各 器管の機能検查, 腄㽽位置の彰断等に用いる装置の開発 目的とした。

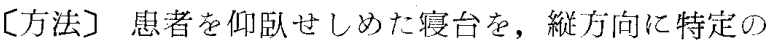
速さを以って走行させる。 その走行範囲の中心部によく コリメートされたシンチレーションデテクタで患者堂保 さんで上下に配置された患者走行の途中に体内 RI の強 度全身分布觉検得する。

〔結果】試作した㖟台部は走行部全長 $400 \mathrm{~cm}$, 全幅70 $\mathrm{cm}$, 天板高さ $70 \mathrm{~cm}$, 天板長 $200 \mathrm{~cm}$, 天板移動範囲 200 $\mathrm{cm}$, 天板移動速度 0.5 分 $/ \mathrm{m}, 2.5$ 分 $/ \mathrm{m}, 5$ 分 $/ \mathrm{m}, 10$ 分 $/ \mathrm{m} \sigma$ 4 段初換, となっている。検出器は $\mathrm{NaI}(\mathrm{Tl})$ クリス夕 ル $2^{\prime \prime} \phi \times 2^{\prime \prime}$ 苍上 2 本使用できる。 また, 测定器に法メ ディカルスペクトロメータを用いている.

\section{（資料展示のみ）}

\section{1. 万能形治療用線量計}

東芝玉川工場

西堀清美・小野伸雄・加藤武司

梠原重泰

〔目的】放射線治療において深部線量の分们, 表面線 量の測定, 散乱線の測定等多目的に使用できる線量計の 開発を目的とする。

[方法]振動容量形電位計と特殊設計による電離槽邑 組み合せて, 万能形の線量計死開発した。

〔結果】開発した振動容量電位計と電離槽による測定 範囲仿次の通りである。

1) 指頭形電離槽
(A) 電離容積 $0.02 \mathrm{cc}$ 最大感度 $5 \mathrm{r} / \mathrm{min}$
(B) 電離容積 $0.2 \mathrm{cc}$ 最大感度 $0.5 \mathrm{r} / \mathrm{min}$
(C) 電離容積 $20 \mathrm{cc}$ 最大感度 $5 \mathrm{mr} / \mathrm{min}$

2）、ファントーム・チェンバー表面線量测定用

3）シャロー, チェンバー 軟 X線電子線測定

（資料展示のみ）

\section{2. 等線量曲線自動描写装置}

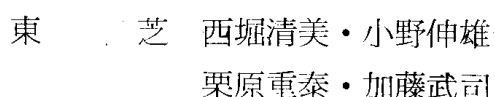

